\title{
Industry and Academia: Together Spells Success
}

Dr. Raymond Edward Floyd, Northwest College 


\section{Industry and Academia: Together Spells Success}

\section{R. E. Floyd, Life Senior IEEE}

Abstract - Whether one looks at engineering or engineering technology curriculums, there is no outstanding indication of the importance of the role Industry can play in the successful completion of a student's preparation for the future. Whether looking at accredited or nonaccredited programs, the importance of Industry's partnering with Academia cannot be overstated. Equally, Academia's work with Industry on curriculum, course content, and other features of program offerings is paramount to the success for the University, the student, and Industry. While there are many ways for Industry and Academia to work together, there are five in particular that can provide a good pathway for success for the student. The first of the five is the establishment of an Industry Advisory Board (IAB). The Board can provide direction and evaluation of the strength of a particular program. The second is through the development of internships, allowing students to understand industry skill needs. Third is a direct help to students through support of Mentors, individuals having particular skills to help the student. Fourth is in providing guest speakers for introductory classes or society meetings. The final area is the donation of new or used equipment common to a particular field, or general test equipment that may be used in multiple lab exercises. These particular areas will be discussed in greater detail in the body of this paper.

Introduction - The greater the interaction between Industry and Academia in curriculum development and course review, the greater the opportunity for engineering students to be prepared for careers in industry [7,8]. This is especially true when the academic program is slanted to local industry needs. There are five general areas that can be emphasized that will best benefit the student:

Advisory Board, Internships,

Mentors,

Guest Speakers, and 


\section{Equipment.}

For accredited engineering and engineering technology programs, the Advisory Board is an ABET criteria item (Criterion 5 - Curriculum - "An advisory committee with representation from organizations being served by the program graduates..."), thus may have the greatest impact to a school for the particular program being considered for accreditation [1-3]. Even with nonaccredited programs, the Advisory Board can provide great benefits for any particular program student's success. While the remaining four items may not have direct impact to accreditation, each provides an opportunity for a school and industry to cooperate in providing the very best program for the engineering students, building a strong foundation for their selected career.

Advisory Board - The constituency for a particular program consists of three parts, the student(s), the faculty for the program, and the industry community served by the graduates. The board does not have to be particularly large or complex, it simply must be able to evaluate the effectiveness of a particular program in fulfilling the expectations of the students in preparing for their future career and the needs of the industrial opportunities for the student. While the particular curriculum generally cannot be tailored to a specific industry within the local area, it can provide some emphasis for that industry. For example, if a local industry uses a highly automated assembly line, courses involved with embedded controllers and sensors may be appropriate, and still meet the general concept of an elective for the more general course content. In a similar manner, the embedded systems will generally require application programs that provide the sequencing of the process, thus a programming class emphasizing controller programming use may be appropriate and, again, be used as an elective in the overall curriculum.

To be effective, the Advisory Board must meet on a regular basis. This does not mean weekly or monthly, but at least once a year as a minimum, with once a semester being the preferred rate. It is important that each industry representative and faculty member be consistent in their attendance. Students must also be invited in order for them to express their interests. If possible, it would be appropriate to include graduates of the programs to see how the programs prepared

them for their new careers in industry. All facets of any particular program can be reviewed at this meeting, including course content, the course text, and any labs associated with the program, and so forth [6]. There must be open dialog on the curriculum by all participants - it isn't a 
witch hunt, but an attempt to continue to provide the very best material for the benefit of the student.

Internships - Internships are of particular value to the student and to Industry. The internship may be a Summer hire, or could be an alternating semester hire, with repeated opportunities for the industry to evaluate the particular student involved. It also provides the student an experience to the particular facets of an industry, or multiple industries, if they have not yet decided on where they wish to begin their career.

It is important both to the student and the industry involved that the internship provide "real world" work, not drawing filing or other paperwork projects which do not apply to the program the student is following. That is not to say that the student must be given original design work to complete, but rather some small segment of design, drawing modification, subroutine algorithm development, and so forth. The effort must be applicable to the student's development, but able to be completed in the short duration of the student's availability.

In the process of an internship, the student may discover that chemistry is not the field they wish to pursue, but the petroleum industry is. In a similar manner, the company that haves an intern is able to determine if the student is someone they wish to pursue as a permanent employee or not. If there is an interest, the company may also be able to provide direction to the student on the types of course material that would be appropriate for their future school efforts. Industry may also provide the connection discussed in the next section, by providing a mentor for the student as they continue their educational efforts.

The Academic side of internships is important, as the choices and opportunities can frequently be guided by the contacts the academic professors have made over their careers with the local industrial representatives. There is also a need to ensure that any internship that has credits awarded be evaluated by the faculty to ensure the credit and course content is appropriate.

Mentors - An easy way to shape a student's future is through the use of a Mentor [4, 5, 9]. From an academic perspective this role is fulfilled by the Staff advisor that reviews the student's program on a regular basis, typically each semester. During this time, the advisor reviews the student's progress, planned programs, and any prerequisites that may be needed. The biggest 
problem with the academic advisor is that they are most often providing advice to a large number of students, not the best role for a Mentor.

Within industry, Mentors are most often limited to a small number of mentees, typically no more than three. In the Mentor role, the industry engineer may help interns and active students, providing advice on classes to be completed, current problems, or work related items. The Mentor is typically an experienced individual that has been there and done that. The Mentor seldom tells the mentee how and what, but more frequently provides hints and subtle directions in the manner of "Have you tried....?", or "Have you considered...?". More than any other facet, Mentors must be willing to share their experiences, without the belief that they are giving up hard earned experience for themselves, or they believe the student is an adversary trying to steal their knowledge..

Guest Speakers - An engineering class can benefit greatly thorough the use of guest speakers who are knowledgeable about a particular field of study or application. Industry has the experienced engineers who can provide students insights into any particular field of study, and may provide some insight into the types of classes that those wishing to follow in that particular field of study may want to include in their curriculum. From an Academic perspective, such outside speakers may provide additional insight and course emphasis for their assigned classes. The particular field is not critical. The more varied the particular field the better, as it offers the students a wider perspective on the possibilities of an engineering career. Where possible, the guest speakers should include women and minority engineers, so they may offer their unique experiences for the students, both good and bad.

There are a couple of things the Professor should do for the guest speaker. First, a lunch prior to, or after, the presentation would be appropriate - even if at the school cafeteria. The cost is minimal when compared to the benefits gained by the students. Second, there should be a letter sent to the guest speaker, with a copy to their supervisor, thanking them for their time and effort on behalf of the School and students. It isn't a big deal, but will always be appreciated by the speaker, and will look good in their personnel file.

Equipment - A major problem for most Universities and Colleges is in providing modern, current, equipment for labs. Typically, the equipment in engineering labs is ten, or more, years 
old and hasn't been calibrated in the time it has been at the school. Similarly, few schools can afford to include a paid staff member to track, calibrate, and repair equipment over time. The exception to this is the Information Technology Department where, in most cases, there will be a budget to ensure frequent updates and replacements for their equipment.

Industry, on the other hand, will seldom have equipment more than five years old, simply because the technology changes rapidly. The old equipment is still serviceable, but has been written off from a tax credit perspective. Such equipment would benefit a University lab, and could be written off as a donation on behalf of the Industry involved. Even when the equipment is non-functional, such donations could benefit the University through spare parts, learning trouble shooting techniques, and general knowledge of circuits and components on behalf of the students involved.

Conclusion - The importance of close cooperation between Industry and Academia cannot be overstressed. The benefits to the engineering students cannot be weighed, other than to say that the benefits are multifaceted - career specific insight, career objectives and planning, and industry specific knowledge are all benefits to the student engineer. Most cooperative actions are initiated by the University or College. The derived action plan is a joint effort by the school and the industry representatives. It is important that a plan be developed and initiated - it is for the benefit of the student, and that should always be an objective for any such program. Most importantly, it must be a living, dynamic plan. It cannot be established and then forgotten. The effort is not great, but the impact is.

References

1 ABET (2016), Accreditation Policy and Procedure Manual, ABET, Baltimore, MD.

2 ABET (2016), Criteria for Accrediting Engineering Programs, ABET, Baltimore, MD.

3 ABET (2016), Criteria for Accrediting Engineering Technology Programs, ABET Baltimore, MD.

4. A. Tjan (2017). "What the Best Mentors Do", Harvard Business Review, 2/27/17. http://www.hbr.org/article/what-the-best-mentors-do/html [Accessed March 27, 2017)]

5. A. Dasgupta (2017). "Finding the right fit in academia and industry collaboration". Geospatial World, May 23, 2017. 
6. C. McIntyre (2015). "Developing a 'High-Impact' Industry Advisory Board”. 2015 Industry Advisory Board (IAB) Event, February, 2015.

7. J. Martin (2002). "Academic-industrial collaboration: the good, the bad, and the ugly".

Transactions of the American Clinical and Climatogical Association, 2002-113, pgs 227239.

8. M. Young, "Industry, Academia, and Government Collaboration: A Game Changer for U.S. Economic Future”, Business Horizon Quarterly, Issue 7, pgs. 17-21.

9. - "The Mentoring Relationship includes a Mentor and a Mentee". Staff Development and Professional Services, University of California - Davis. [Accessed March 15, 2017].

http://sdps.ucdavis.edu/toolkits/mentoring. 